Edukacja Dorostych 2020, $n$ r 2

ISSN 1230-929 X

http://dx.doi.org/10.12775/ED.2020.012

\author{
Renata Pomarańska
}

ORCID: 0000-0003-3632-8086

\title{
HARMONIA ŻYCIA ZAWODOWEGO I CZASU WOLNEGO W ŻYCIU KOBIET W POLSCE W PERSPEKTYWIE ANDRAGOGICZNEJ
}

\begin{abstract}
Słowa kluczowe: work-life balance, praca zawodowa, czas wolny, budżet czasu, model andragogiczny.

Streszczenie: Aktywność zawodowa kobiet w Polsce należy do zjawisk powszechnych. Wiąże się to jednak najczęściej z deficytem czasu wolnego w ich budżecie czasu. Do tej kwestii nawiązuje koncepcja work-life balance, która stawia sobie za cel równoważenie obu ważnych sfer życia człowieka. W artykule podjęto temat harmonii życia zawodowego i czasu wolnego w życiu kobiet w Polsce w perspektywie andragogicznej. Jego problem stanowi odpowiedź na pytania, czym jest praca zawodowa i czas wolny w życiu kobiet oraz jaki wpływ na harmonię życia zawodowego i czasu wolnego kobiet może mieć andragogika. Odpowiedzi na te pytania są budowane na podstawie literatury przedmiotu, dostępnych danych statystycznych oraz wyników dostępnych badań i analiz. W artykule skupiono się przede wszystkim na kobietach dorosłych, które zakończyły edukację formalną.
\end{abstract}

\section{Wstęp}

Problematyka kariery zawodowej i życia prywatnego zarówno kobiet, jak i mężczyzn stanowi przedmiot zainteresowania wielu dziedzin i dyscyplin naukowych, wśród których można wymienić m.in. pedagogikę, psychologię, socjologię, jak również demografię, biologię, medycynę czy ekonomię. Świadczy to o złożonym aspekcie tego zagadnienia. Przede wszystkim jednak umiejętność łączenia życia zawodowego i czasu wolnego jest niezwykle istotna w życiu kobiet, doświadczających macierzyństwa, opieki nad dziećmi, zajmujących się domem, coraz częściej, ale nie zawsze, wspieranych przez mężczyzn (por. Giddens, 2012, s. 141).

Problem godzenia życia zawodowego z osobistym jest dla nich jedną z istotniejszych kwestii w życiu. Poszukują one nowej tożsamości, nie chcąc być jedynie spełnionymi żonami i matkami, ale także dążąc do samorealizacji w życiu 
zawodowym. Tymczasem, jak zauważa amerykańska socjolog Arlie Hochschild, choć kobiety zyskują coraz większe prawa na rynku pracy, nadal na nich ciążą obowiązki domowe, co według niej świadczy o niedokończonej rewolucji kobiet (por. cyt. za Giddens, 2012, s. 421).

W związku z tym wzrosło zainteresowanie życiem kobiet w odniesieniu do relacji praca zawodowa - czas wolny. Wynikiem tego są opracowania polskie i zagraniczne; ich rozwój zaobserwowano szczególnie w latach 60. i 70. XX wieku, co było reakcją na pracoholizm i wydłużanie się czasu pracy, a skracanie czasu wolnego.

Początek XXI wieku spowodował zmianę w podejściu do życia zawodowego i czasu poza nim. W wyniku wzrostu oczekiwań pracowników formułowanych w stosunku do środowiska pracy i zatrudniających ich pracodawców dowartościowaniu podlegał czas poza pracą, co wpisuje się w koncepcję work-life balance, mającą na celu podnoszenie poziomu i jakości życia ludzi. Jest to priorytetowy element w wielu strategicznych działaniach Unii Europejskiej, co wynika z dużego zróżnicowania w poziomie i jakości życia ludzi w krajach UE i ich poszczególnych regionach.

Zagadnienie jest zatem aktualne. Porusza harmonię życia zawodowego i czasu wolnego w życiu kobiet w perspektywie andragogicznej. W związku z tym rodzi się problem, czym jest praca zawodowa i czas wolny w życiu kobiet oraz jakie wyzwania stoją przed andragogiką w kontekście work-life balance kobiet. Dlatego w artykule skupiono się przede wszystkim na kobietach dorosłych, które zakończyły edukację formalną. Z racji tego, że andragogika odnosi się do kształcenia, samokształcenia, wychowania i samowychowania w celu wyrównania braków w kształceniu szkolnym dorosłych, uzupełnienia i zaktualizowania ich wiedzy.

Przy opracowaniu wykorzystano literaturę przedmiotu, dostępne dane statystyczne oraz wyniki dostępnych badań i analiz. Zastosowano metody analizy i syntezy oraz metodę porównawczą. Studium ustrukturyzowano w trzy części.

\section{Rys pracy zawodowej kobiet w Polsce (XIX-XXI w.)}

Praca stanowi jeden z tych obszarów aktywności człowieka, który decyduje o przetrwaniu, rozwoju i doświadczeniu satysfakcji życiowej. W przypadku kobiet, gdy sięgnie się do niezbyt odległej nawet przeszłości, ich aktywność zawodowa była redukowana przez bariery obyczajowe i prawne.

W XIX wieku akceptowano pracę zarobkową kobiet z niższych warstw społecznych, ale praca kobiet $\mathrm{z}$ warstw zamożniejszych nie spotykała się z aprobatą ze strony ich własnego środowiska. Dopuszczano natomiast pracę na rzecz rodziny, która była nieopłacaną codzienną aktywnością pielęgnacyjno-wychowawczo-gospodarczą. Nie dającej się jednoznacznie określić w czasie, pozbawionej możliwości przeciwstawienia jej czasu wolnego i tradycyjnego rozróżnienia na pracę oraz święto (por. Zadrożyńska, 1986, s. 50-80), pracę w domu podnoszono do 
rangi misji rodzinnej. W związku z tym do ostatniego ćwierćwiecza XIX wieku w procesie unowocześniania się stosunków pracy kwestia życia zawodowego kobiet niezwykle rzadko była podnoszona.

Początek wieku XX również nie zdołał wyeliminować tkwiących w tradycji i stereotypach, będących przeszkodą w rozwoju aspiracji zawodowych kobiet, barier i ograniczeń, które nadal pozostawały przeciwstawiane powołaniu kobiety do roli żony, matki i strażniczki domowego ogniska. Dopiero w latach 1921-1931 nastąpił o prawie $60 \%$ przyrost odsetka zatrudnionych kobiet, co było jednak sytuacją przejściową. Tłumaczy się to wpływem kryzysu gospodarczego i zatrudnianiem kobiet jako tańszej siły roboczej (por. Żarnowski, 2000, s. 121). Na podstawie danych ze spisów ludności z 1921 i 1931 roku J. Żarnowski podaje, że stosunkowo najwięcej przybyło pracownic umysłowych (68\%), następnie robotnic $(63 \%)$, w końcu samodzielnych niezatrudnionych sił najemnych: drobny handel, rzemiosło, wolne zawody (58\%) (por. tamże, s. 123). Stanowiska pracownic umysłowych zajmowały głównie kobiety pochodzące z warstwy inteligencko-mieszczańskiej, podobnie jak w przypadku wolnych zawodów. O ile praca kobiet w biurach była już przed I wojną światową zjawiskiem nierzadkim, a w okresie powojennym, gdy nastąpił rozrost biurokracji, zapotrzebowanie na tę profesję wzrosło, o tyle powierzanie kobietom - choć rzadko - odpowiedzialnych i samodzielnych stanowisk było nowatorskie i wiązało się także z coraz lepszym wykształceniem kobiet. Najczęściej funkcje kierownicze kobiety pełniły w sekretariatach i bibliotekach (por. tamże, s. 127).

Od XIX w., kiedy przyznano kobietom prawo do zatrudnienia w odniesieniu do szkół elementarnych, społecznie aprobowano pracę kobiet jako nauczycielek. Zaznaczyło się to przewagą kobiet na wszystkich szczeblach personelu nauczającego (zob. Smolalski, 1996, s. 51-52). W okresie międzywojennym przewaga kobiet zaczęła się zmniejszać. W szkołach średnich kobiety stanowiły 30-40\%. W tym czasie wzrosła liczba męskich kandydatów do zawodu (por. Żarnowski, 2000, s. 130).

Inna była sytuacja w grupach zawodowych poza nauczycielstwem. J. Żarnowski mówi w tym względzie o trzech kategoriach: do niektórych zawodów kobiety nadal nie miały wstępu, w innych pojawiały się pierwsze przedstawicielki, a w jeszcze innych stanowiły już widoczną mniejszość (por. tamże, s. 131).

Stanowiska kierownicze w administracji centralnej i terenowej czy samorządzie terytorialnym, co najmniej do poziomu naczelnika wydziału, były dla kobiet nieosiągalne, nawet w zawodach, w których kobiety stanowiły nieraz przewagę, jak np. w szkolnictwie. W zasadzie nie zatrudniano kobiet jako sędziów ${ }^{1}-\mathrm{z}$ wyjątkiem kilku dla nieletnich, prokuratorów, notariuszy, służb wojskowych i policji

Pochodzący z 1919 r. dekret o aplikacji sądowej przewidywał mianowanie na stanowiska sędziowskie wyłącznie mężczyzn. Zgodnie zjego postanowieniami kobiety mogły odbywać aplikację sądową tylko jako przygotowanie do zawodu adwokata, zob. Dekret Naczelnika Państwa z dnia 8 lutego 1919 r. o aplikacji sądowej (Dz. Pr. P. P. Nr 18, poz. 225). 
oraz na stanowiskach dyplomatycznych w Ministerstwie Spraw Zagranicznych i placówkach, co zresztą nie było tylko polską domeną.

Do wykonywania niektórych zawodów dopuszczano kobiety niezwykle rzadko. Przed II wojną światową na ok. 800 profesorów wyższych uczelni przypadało zaledwie kilka kobiet. Częściej spotykało się kobiety wśród docentów. Powodów należy szukać zarówno w ograniczeniach dostępu kobiet do studiów, jak też w hamowaniu awansu kobiet czy w ogóle niechęci ze strony konserwatywnych profesorów do zajmowania się pracą naukową przez kobiety.

Do grupy zawodów, w których kobiety stanowiły liczącą się mniejszość, należały przede wszystkim wolne zawody. W 1939 r. wśród lekarzy kobiety stanowiły ponad $15 \%$, a w wielkich miastach $20 \%$, nie mówiąc o stomatologii, w której kobiety zaistniały już przed I wojną światową. W połowie lat dwudziestych XX w. pojawiły się pierwsze adwokatki, by pod koniec dwudziestolecia stanowić już kilka procent ogółu. Do wybuchu II wojny światowej ponad 200 kobiet zostało adwokatami. Dynamiczne zmiany dotyczące kobiet w szeregach adwokatury obrazują dane odnoszące się do Izby Adwokackiej w Warszawie, gdzie w 1926 r. była tylko 1 adwokatka i 11 aplikantek, w 1930 r. 24 adwokatki i 52 aplikantki, a w 1934 r. 89 adwokatek (na ogólną liczbę 1844 adwokatów) oraz 112 aplikantek (na ogólną liczbę 695 aplikantów) (por. Stypułkowska, 1994, s. 141). Kobiety mogły również wykonywać pracę radców prawnych. Najczęściej korzystały z ich usług prywatne przedsiębiorstwa, które chciały zaoszczędzić na poradach prawnych, gdyż praca kobiet w tym zawodzie była znacznie tańsza niż mężczyzn (por. Wawrzykowska-Wierciochowa, 1963, s. 388-389).

Niewiele kobiet było wśród dziennikarzy, ok. 1928 r. zaledwie 6-7\%. W zawodach artystycznych kobiety mogły się realizować już od XIX w. Przeszkodę stanowił jednak utrwalony wzorzec kulturowy, według którego kobieta była obiektem w sztuce, a nie jej twórcą (Gromada, Budacz, Kawalerowicz, Walewska, 2015, s. 13). Podobnie rzecz miała się z zawodami technicznymi. Nieliczny udział kobiet $\mathrm{w}$ pracy $\mathrm{w}$ charakterze inżynierów wynikał $\mathrm{z}$ braku adekwatnego sposobu kształcenia kobiet oraz z charakterystyki ówczesnego systemu edukacyjnego, a także z braku możliwości zatrudnienia na stanowiskach inżynierów - kierowników produkcji, a jedynie, i to w ograniczonym stopniu, w biurach projektowych i konstrukcyjnych. W latach trzydziestych XX w. symptomem większego zainteresowania wśród kobiet zawodami technicznymi był wzrost odsetka kobiet wśród studentów uczelni technicznych (zob. Piłatowicz, 1994, s. 49).

Jeśli uznać politykę za zawód, to trzeba stwierdzić, że udział kobiet w polityce został przyjęty już na przełomie wieków głównie w środowiskach lewicowo-socjalistycznych. Przyznanie kobietom pełni praw wyborczych na mocy dekretu Naczelnika Państwa z dnia 28 listopada 1918 r. sprawiło, że mogły one uczestniczyć w życiu politycznym na równi z mężczyznami (por. Hass, 1996, s. 73). Mimo to do przełomu w tej dziedzinie nie doszło. Aktywność polityczna kobiet w Polsce międzywojennej była niska, czego dowodzi liczba zdobywanych przez nie mandatów 
parlamentarnych. Udział kobiet w obydwu izbach polskiego parlamentu pozostawał przez cały okres międzywojenny bardzo skromny, gdyż łącznie piastowały one 41 mandatów poselskich i 20 senatorskich (por. Fuszara, 2007, s. 87).

Zupełnie inna, i to od poprzedniego wieku, była w dwudziestoleciu międzywojennym sytuacja kobiet robotnic, które stanowiły ok. 30\% ogółu robotników. Różnice w zatrudnianiu miały charakter regionalny. I tak w przemyśle włókienniczym w Łodzi zatrudniano głównie kobiety, a w górnictwie na Śląsku - przeważnie mężczyzn. Sytuacja kobiet w środowisku robotniczym ulegała zmianom w okresie kryzysu gospodarczego w latach 1929-1933. Pracodawcy chętniej zatrudniali kobiety jako tańszą siłę roboczą (por. Krahelska, 1932, s. 24) oraz w zastępstwie za młodocianych, których zatrudnianie zostało ograniczone przez przepisy.

Po II wojnie światowej wzrosła liczba kobiet będących jedynymi żywicielkami rodziny, zmuszonych sytuacją życiową do znalezienia źródła utrzymania. W owym czasie kobiety podejmowały więc masowo pracę w fabrykach, usługach i urzędach (por. Kurzynowski, 2000, s. 189). Nad wyraz silnie tendencja ta uwidaczniała się w miastach. Na 100 mężczyzn w 1945 r. przypadało 128 kobiet, w 1946 r. - 122, 1947 r. - 118, 1949 r. - 115, 1950 r. - 118 (por. Jarosz, 2000, s. 219). Dodatkowym czynnikiem był kult pracy, charakterystyczny dla każdego komunistycznego kraju, w tym Polskiej Rzeczypospolitej Ludowej. Ponadto w związku z propagowaną $\mathrm{w}$ tamtych czasach ideą równouprawnienia płci kobietom zagwarantowano zarówno prawo do edukacji, jak i podjęcia pracy zarobkowej. W okresie realizacji planu sześcioletniego liczył się każdy pracownik. Akcja propagandowa w mediach służyła zachęcaniu kobiet do podjęcia pracy zawodowej. W okresie stalinizmu powstały plakaty z podobizną traktorzystki, a kroniki filmowe informowały o kobietach-tokarzach i przodowniczkach pracy (zob. Polskie Kroniki Filmowe, 1951). Na stanowiskach wcześniej zarezerwowanych dla mężczyzn zatrudniano kobiety, jak na przykład w kopalniach, gdzie wykonywały pracę lepiej płatną (por. Mrozek, 2019, s. 263). W latach 1952-1955 liczba pracujących kobiet wzrastała szybciej niż mężczyzn. W 1950 roku 31,2\% kobiet przypadało na 100 zatrudnionych, a w 1954 -33\% (por. Wieruszewski, 1975, s. 111).

Po październikowej odwilży 1956 r. sytuacja kobiet na rynku pracy zaczęła się zmieniać na ich niekorzyść. Wykwalifikowani robotnicy, którymi byli głównie mężczyźni, zapragnęli powrotu tradycyjnego podziału obowiązków kobiet i mężczyzn, w efekcie czego media tym razem zaczęły potępiać pracę zawodową kobiet. Przekładało się to także na stosunki pracownicze. Przy awansach kobiety były coraz częściej pomijane i przy każdej sposobności zwalniane. W 1960 r. ich udział w zatrudnieniu wynosił 32,8\% (por. tamże, s. 112-113). Następne lata przyniosły kolejne zmiany w polityce zatrudnienia kobiet. Tym razem, chcąc pogodzić interesy mężczyzn-robotników z zasadami równouprawnienia, przedstawiano role matki i pracownika jako równorzędne (por. Markowska, 1986, s. 200). Jednak w ciągu 10 lat udział kobiet wśród wszystkich zatrudnionych wzrósł o prawie 7\% 
(por. Wieruszewski, 1975, s. 107). W niektórych sektorach zatrudniano przeważnie kobiety: ochrona zdrowia $-80,2 \%$, instytucje finansowe $-70,7 \%$, oświata $67,1 \%$, obrót towarowy $-64,1 \%$ oraz administracja publiczna $-53,6 \%$ (por. cyt. za Wrochno, 1969, s. 42). Sfeminizowane zawody oferowały niskie zarobki i nie cieszyły się takim prestiżem jak zawody, w których przeważali mężczyźni (por. Gąciarz, 2011, s. 322). Zajmowanie przez kobiety prestiżowych społecznie stanowisk, jak wykładowcy wyższej uczelni, adwokata czy sędziego, wyglądało nieco lepiej niż w II Rzeczypospolitej. W najlepszym momencie, to jest w latach 1980-1985 , kobiety stanowiły $35 \%$ wszystkich zatrudnionych na uczelniach wyższych. Zajmowały przede wszystkim najniższe stanowiska, niezwiązane z awansem: wykładowców i lektorów. Tytuł profesora zaś był silnie zmaskulinizowany. Zaszczytu tego dostąpiło w 1955 r. 6\% kobiet spośród ogółu doktorów habilitowanych, a w 1985 - 13\% (por. Mrozek, 2019, s. 275). W zawodach prawniczych w 1968 roku było w Polsce 12,8\% kobiet adwokatów, w 1974 - 15,8\%, a w $1980-19 \%$ (por. Fuszara, 2007, s. 76). Lepiej prezentują się dane odnoszące się do funkcji sędziego. Chociaż w 1968 r. pełniło ją 33,2\% kobiet wśród ogółu osób na tym stanowisku, to w 1985 wynik ten wynosił 52,9\% na rzecz płci żeńskiej (por. tamże, s. 68).

Po transformacji ustrojowej w 1989 r. doszło do znacznego spadku zatrudnienia kobiet. Okres reformowania gospodarki w latach dziewięćdziesiątych cechował spadek poziomu aktywności zawodowej z 65,3\% (NSP 88) do 61,4\% w II kwartale 1992 r. (gdy wprowadzono badanie aktywności ekonomicznej ludności) i 56,6\% w IV kwartale 1999 r. Aktywność zawodowa kobiet spadła z 57\% do $49,7 \%$ (por. Kowalska, 2000, s. 52). Kobiety były zatem bardziej zagrożone bezrobociem, dłużej pozostawały bez pracy (bezrobocie długotrwałe), trudniej też im było powrócić na rynek pracy po okresie dezaktywizacji zawodowej oraz wejść na rynek pracy po zakończeniu nauki.

Do najbardziej sfeminizowanych sektorów należały ochrona zdrowia i opieka socjalna (463 kobiety na 100 mężczyzn), edukacja (282 kobiety na 100 mężczyzn) i pośrednictwo finansowe (279 kobiet na 100 mężczyzn). Według danych Badania Aktywności Ekonomicznej Ludności (BAEL) w latach 1994-1998 wzrosła feminizacja $\mathrm{w}$ pośrednictwie finansowym i administracji publicznej. W liczbach bezwzględnych wzrosła liczba kobiet pracujących w działalności produkcyjnej, handlu i naprawach, hotelach i restauracjach, transporcie i łączności, pośrednictwie finansowym, obsłudze nieruchomości i firm, administracji publicznej oraz w ochronie zdrowia i opiece socjalnej (por. tamże, s. 59-60).

Z danych BAEL za IV kwartał 2003 r. wynika, że wskaźnik zatrudnienia kobiet jest prawie o 1/4 niższy niż wskaźnik zatrudnienia mężczyzn. Pracujące kobiety w większości mają co najmniej średnie wykształcenie. Rzadko jednak zajmują stanowiska kierownicze, szczególnie wyższego szczebla. W grupie zawodów kierowniczych kobiety stanowiły w 2003 r. 35\%. Tylko 29\% pracodawców to kobiety. Najbardziej sfeminizowaną grupą zawodową jest grupa pracowników 
biurowych, w której w 2003 r. na 100 mężczyzn przypadało 235 kobiet (por. Główny Urząd Statystyczny, 2004).

Między 2010 a 2013 r. współczynnik aktywności zawodowej kobiet (ogółem) wzrósł o 1,0 pkt. proc. do 48,5\%, natomiast dla mężczyzn wskaźnik ten zwiększył się w tym okresie zaledwie o 0,5 pkt. proc. do $64,4 \%$. Kobiety najczęściej wykonywały prace w zawodach należących do grup: pracownicy biurowi, pracownicy usług osobistych i sprzedawcy oraz specjaliści. W 2013 r. w każdej z nich kobiety stanowiły około 64\% ogółu pracujących (por. Główny Urząd Statystyczny, 2014).

Nie ulega kwestii, że w ostatnich latach aktywność zawodowa kobiet w Polsce przeważnie rośnie, choć wskaźnik zatrudnienia nadal jest wyraźnie wyższy w populacji mężczyzn niż kobiet. W III kwartale 2020 r. wyraźnie wyższy wskaźnik zatrudnienia obserwowano wśród mężczyzn (odpowiednio 63,3\% wobec 46,5\% dla kobiet) (por. Główny Urząd Statystyczny, 2020).

Jak zwiększała się aktywność zawodowa kobiet po II wojnie światowej można wykazać przez porównanie poszczególnych danych odnośnie do udziału kobiet w liczbie zatrudnionych w Polsce - w 1950 r. wyniósł on ok. 31\%, na początku lat 70. przekroczył 40\%, a od roku 2014 do 2016 utrzymywał się na poziomie blisko 49\%. W 2016 r. nastąpił kolejny spadek aktywności zawodowej kobiet w Polsce.

Życie zawodowe stanowi część życia ludzi. Za przeciwieństwo pracy zawodowej, będącej punktem wyjścia i odniesienia na zasadzie dychotomii, zwykło się uważać czas wolny.

\section{Czas wolny w życiu kobiet}

Nauki społeczne pojęcie czasu wolnego tłumaczą w różny sposób. W socjologii przyjmuje się najczęściej definicję podaną przez twórcę socjologii wypoczynku. Według J. Dumazediera wolny czas - to wszelkie zajęcia, którym jednostka oddawać się może z własnej chęci bądź dla odpoczynku, bądź dla rozrywki, bądź dla rozwoju swych wiadomości lub swego ksztatcenia bezinteresownego, swego dobrowolnego udziału w życiu społecznym po oswobodzeniu się z obowiązów zawodowych, rodzinnych, spolecznych (cyt. za Czajka, 1979, s. 39). Definicja ta była inspiracją dla teorii stworzonych na gruncie pedagogiki społecznej w kontekście polskiej literatury przedmiotu. Natomiast reprezentujący pedagogiczny sposób podejścia A. Kamiński stwierdza, że czas wolny jest to ta część budżetu czasu, która nie jest zajęta przez pracę zarobkowa normalna i dodatkowa, ani przez systematyczne ksztatcenie się uczelniane, ani przez zaspokojenie elementarnych potrzeb fizjologicznych (sen, positki, higiena), ani przez state obowiazki domowe (gotowanie, pranie, sprzatanie, opieka nad członkami rodziny niezdolnymi do samoobstugi) i może być spożytkowana bądź na swobodne wczasowanie, bądź na życie rodzinne, obowiązi społeczne i aktywność przynoszaca doraźne korzyści (Kamiński, 1972, s. 297). 
Obie definicje wskazują na zaspokajanie w czasie wolnym od pracy potrzeb człowieka, które może mieć miejsce w domu (np. oglądanie telewizji, odpoczynek, korzystanie z komputera, czytanie książki), jak też w placówkach/instytucjach usługowych (np. kino, teatr, klub fitness, restauracja) oraz w środowisku naturalnym (np. las, park) (por. Kolny, 2014, s. 28-38).

Jan Pięta w Pedagogice czasu wolnego przybliża współczesne formy spędzania wolnego czasu. Wśród najczęściej praktykowanych wymienia turystykę, sport i środki masowego przekazu (por. Pięta, 2014, s. 79-101).

Z turystyką związane są zmiany miejsca pobytu niepowiązane z pracą zawodową lub zmianą miejsca zamieszkania. Obecnie ta forma spędzania wolnego czasu stała się dostępna dla milionów Polaków, ale jeszcze niedawno tylko warstwy uprzywilejowane mogły sobie na nią pozwolić. W kontekście wolnego czasu turystykę należy uznawać za ważny element rekreacji i życia kulturalnego społeczeństwa.

Sposobem na spędzanie czasu wolnego jest także sport, na który spogląda się z dwóch perspektyw. Po pierwsze sport może być widowiskiem, na które człowiek patrząc, relaksuje się, a po drugie sport można uprawiać czynnie. I w jednej, i drugiej postaci absorbuje sporą część wolnego czasu.

Korzystanie ze środków masowego przekazu, a więc podstawy komunikowania w kulturze masowej, może być równie atrakcyjnie zagospodarowanym czasem wolnym. Prasa, książki wysokonakładowe, radio, telewizja, Internet itp. dostarczają wielu rozrywek i zaspokajają gusty szerokiego grona odbiorców.

Istnieją też inne formy spędzania wolnego czasu, które interesują tylko określone grupy, różniące się od siebie wykształceniem, zawodem, statusem materialnym czy wiekiem (zob. tamże, s. 103-113). Często z pomocą tym wyselekcjonowanym kręgom odbiorców przychodzą z pomocą instytucje kultury, takie jak teatry, filharmonie, muzea czy wystawy. Ma to związek z zaspokajaniem wyższych potrzeb kulturalnych, przeżyć estetycznych i doznań artystycznych.

Znacznie mniejszy zasięg społeczny i terytorialny, według J. Pięty, mają takie formy spędzania czasu wolnego, jak samokształcenie, amatorstwo artystyczne, majsterkowanie i amatorstwo techniczne, hodowla amatorska, zabawy i kontakty towarzyskie, kolekcjonerstwo lub aktywność społeczna (por. tamże, s. 115-131). Niemniej jednak ich wpływ na jakość życia jednostek i grup może być równie ważny jak w przypadku poprzednich form wczasowania.

Czas wolny, bez względu na preferowane formy jego zagospodarowania, pełni istotną rolę w różnych obszarach ludzkiego życia. Badacze wyróżniają wiele funkcji czasu wolnego. Według E. Wnuka-Lipińskiego za fundamentalne można przyjąć, że są to funkcje: wypoczynkowa, kulturalna, integracyjna, rekreacyjna, ekonomiczna, kompensacyjna, kształceniowa i wychowawcza (zob. Wnuk-Lipiński, 1972, s. 28-31).

Współcześnie rozumienie czasu wolnego i problemów z nim związanych nie jest już takie jednoznaczne. Czas wolny sprzęga się z czasem pracy 
i często trudność sprawia jednoznaczne oddzielenie jednej kategorii od drugiej. Jest to zwiazane z przemianami czasu wolnego, jego koncepcji i struktur w kulturze wspótczesnej. A także ze sprawa kluczowa - z przeksztatceniami statusu i roli pracy, z procesami sprawiajacymi, że praca staje się kurczacym się lub nawet zanikającym wymiarem życia jednostek. [...] W świecie wspótczesnym obserwujemy upadek tradycyjnego systemu pracy w zwiazku z takimi zjawiskami, jak chroniczne bezrobocie czy różne formy skracania czasu pracy w ciagu życia człowieka (Tarkowska, 2001, s. 27), a także wzrostem liczby przedsiębiorców bądź ludzi wykonujących wolne zawody, którym sprawia trudność rozgraniczenie pracy od czasu poza nią. Współczesne społeczeństwa charakteryzują się z jednej strony deficytem pracy i nadmiarem czasu wolnego, a z drugiej - przeciążeniem pracą, a niedoborem czasu niepracy.

W okresie PRL-u, zgodnie z socjalistycznym poglądem, w centrum uwagi stawiano pracę. Czas wolny rozumiano jako czas, który pozostaje po spełnieniu wszystkich powinności wynikających z pracy zawodowej. Dlatego próbowano tym terminem objąć zarówno różne formy dokształcania - kursy czy studia zaoczne jak też wszelkiego rodzaju zabiegi higieniczne i kosmetyczne.

Okres ten cechował się wysokim budżetem czasu wolnego dla pracowników z wyższym wykształceniem, zwłaszcza technicznym (por. Wnuk-Lipiński, 1981, s. 150). Brak czasu wolnego dotyczył natomiast osób o niskich kwalifikacjach, z niskimi dochodami i trudną sytuacją życiową wynikającą np. z wielodzietności i konieczności opieki nad dziećmi. W najgorszej sytuacji były pracujące zawodowo kobiety, przy tym obciążone dodatkowo obowiązkami domowymi i rodzinnymi (por. Strzemińska, 1970, s. 16). Mężczyźni bowiem obowiązkom domowym poświęcali o 60-70\% mniej czasu niż kobiety (por. tamże, s. 165), które również czas urlopu wykorzystywały na bardziej zaawansowane prace domowe (zob. Morawska, 1951, s. 72-73).

Podobne dysproporcje w zakresie czasu pracy i czasu wolnego kobiet i mężczyzn utrzymywały się przez bardzo długi okres, a nawet spotykane są współcześnie. Badania budżetów czasu z 1996 r. wykazały, że co prawda kobiety pracują dwa razy krócej niż mężczyźni, ale trzykrotnie więcej czasu poświęcają życiu domowemu (por. Główny Urząd Statystyczny, 1998, s. 41).

Proces transformacji ustrojowej i towarzyszące mu zmiany społeczno-gospodarcze spowodowały przemiany również w obszarze pracy, $\mathrm{w}$ tym $\mathrm{w}$ podejściu Polaków do niej i jej miejsca w systemie wartości. Wyniki diagnozy społecznej dowodzą, że pracę traktują oni jako jedną z najważniejszych wartości, wskazując ją na trzecim miejscu, po zdrowiu i udanym małżeństwie i obok dzieci (zob. Czapiński, Panek, 2013). Z jednej strony wysoka stopa bezrobocia, a z drugiej konsumpcyjne podejście do życia były wystarczającą motywacją, by wydłużać czas pracy kosztem czasu wolnego. Przeprowadzone przez GUS w 2013 r. badanie budżetu czasu ludności wykazało, że kobiety $(\mathrm{K})$ nieco więcej czasu niż mężczyźni (M) poświęcały na czynności fizjologiczne $(\mathrm{K}-47,3 \%, \mathrm{M}-45,7 \%$ doby) 
oraz na obowiązki związane z pracą zawodową, zajęciami i pracami domowymi, nauką oraz pracą $\mathrm{w}$ organizacjach, pomocą innym, zaangażowaniem $\mathrm{w}$ działalność organizacji i praktyki religijne ( $\mathrm{K}-30,3 \%, \mathrm{M}-28,5 \%$ doby). Mniej czasu niż mężczyźni mogły natomiast przeznaczyć na odpoczynek $(\mathrm{K}-18,1 \%, \mathrm{M}-21,1 \%$ doby) (zob. Główny Urząd Statystyczny, 2013).

L. Stanek, odwołując się do przywołanej wcześniej definicji czasu wolnego Dumazediera, zauważa, że czas wolny w hierarchii wartości każdego człowieka zajmuje ważne miejsce, wpływając na jego osobowość i jakość życia (por. Stanek, 2011, s. 174). Autonomicznie dokonywane wybory związane są z innymi preferowanymi przez jednostkę wartościami. Dla osób spędzających czas w gronie rodzinnym to właśnie rodzina jest najważniejszą wartością, dla której gotowi są przeznaczyć swój czas wolny. Dlatego Diagnoza Społeczna 2013 uwzględniała w badaniu problem godzenia posiadania dzieci i pracy zawodowej. Zadano w niej pytania o rozwiązania, które ułatwiłyby godzenie pracy zawodowej z obowiązkami rodzinnymi, w tym zwłaszcza z obowiązkami rodzicielskimi. Najczęściej wskazywanymi jako preferowane rozwiązania przez kobiety (ale i podobnie mężczyzn) były:

- elastyczny czas pracy - wskazany przez prawie $57 \%$ kobiet,

- lepsze możliwości opieki poza domem nad dziećmi do 7 roku życia - wymieniło je $37 \%$ kobiet,

- wyższe zasiłki - według 22\% kobiet,

- możliwość wykonywania części pracy w domu, wskazywana przez co prawie czwartą kobietę (por. Czapiński, Panek, 2013, s. 130).

Zaproponowane rozwiązania przyczyniłyby się do zwiększenia ilości czasu wolnego w budżecie czasu kobiet. Pozwoliłoby to efektywniej go wykorzystywać, by móc czerpać większą satysfakcję z życia, wybierając odpowiednie dla siebie formy spędzania wolnego czasu. Wskazują na to także niektóre badania pokazujące, że elastyczność w pracy obniża poziom stresu wśród pracowników (Golden, Veiga, 2005; Kurland, Bailey, 1999). Dickisson zauważa ponadto, iż pracownicy zatrudnieni w organizacjach preferujących elastyczny czas pracy mają mniej dni wolnych z powodu choroby i często są bardziej kreatywni (Dickisson, 1997).

$\mathrm{Z}$ badania na temat życia kulturalnego i sposobów spędzania wolnego czasu, przeprowadzonego w 2018 r. dla serwisu ciekaweliczby.pl na panelu „Ariadna”, wynika, że do najczęstszych aktywności kulturalnych wśród kobiet należy czytanie książek. Taką odpowiedź wskazało $66 \%$ badanych. Na drugim miejscu znalazło się uczestnictwo w plenerowych wydarzeniach kulturalnych $-48 \%$. Do kina chodzi $38 \%$, a do teatru $17 \%$. Częściej niż w przedstawieniach teatralnych kobiety biorą udział w koncertach - 28\%. Mniej kobiet jako sposób na spędzanie wolnego czasu wybiera wizyty w galeriach sztuki - $9 \%$ i bywa na występach kabaretowych $-8 \%$, a najrzadziej kobiety wybierają operę - zaledwie 4\%. 13\% kobiet nie podjęło żadnej z wymienionej aktywności w ciągu ostatniego roku (por. „Ariadna”, 2021). 
Opublikowane przez GUS w 2016 r. wyniki badań „Uczestnictwo w sporcie i rekreacji ruchowej" pokazały, że w zajęciach sportowych i rekreacyjnych uczestniczyło 45\% Polek. 20,6\% deklarowało regularny, a 24\% sporadyczny charakter podejmowanych zajęć. Systematyczność rozkłada się różnie. Najwięcej, bo 30,1\% uczestniczy w zajęciach 1-2 razy w tygodniu, 12\% - 3-5 razy w tygodniu i zaledwie $2,7 \%$ ponad 5 razy w tygodniu (por. Główny Urząd Statystyczny, 2017, s. 48-54).

Zaprezentowane dane pokazują, że kobiety ciągle nie mają wystarczającej ilości wolnego czasu, co wpływa na ich jakość życia. Oprócz oczekiwanych rozwiązań polityki rodzinnej istotnego znaczenia nabiera edukacja ludzi dorosłych, zwłaszcza uczenie się nieformalne. W świetle teorii pedagogicznych niezwykle ważne jest intencjonalne wychowanie młodych ludzi do racjonalnego i wartościowego wykorzystania czasu wolnego, ale równie istotne powinno być przygotowanie zwłaszcza kobiet do równoważenia życia zawodowego ze sferą poza nim. Wydaje się, że temu zadaniu może sprostać andragogika, będąca przede wszystkim nauką praktyczną. Stawiając diagnozę określonych zjawisk, kreuje ona zamierzone zmiany społeczne, ustalające cele i środki tej działalności. Określana bywa stąd nauką o urzeczywistnianiu zamierzeń (por. Aleksander, 2009, s. 40). Istotne jest także podkreślenie andragogiki jako nauki o całożyciowym uczeniu się (Malewski, 2007, s. 54).

\section{Wyzwania dla andragogiki w kontekście work-life balance kobiet}

Idei work-life balance nie można utożsamiać z kategorią czasu wolnego, gdyż jej istota definiowana jest jako kierowanie uwagi na zachowania równowagi pomiędzy życiem zawodowym a życiem osobistym, co umożliwia jednocześnie dażenie jednostki do samorealizacji w poza pracowniczych aspektach życia przy zachowaniu zrozumienia dla wielowymiarowości sytuacji (Stankiewicz-Mróz, 2008, s. 314), natomiast czas wolny ma węższy zakres i nie uwzględnia obowiązków rodzinnych czy społecznych, które ze swej natury odbywają się poza życiem zawodowym. Mimo to w obu koncepcjach można wyodrębnić te same obszary, gdyż np. wspólne oglądanie telewizji z rodziną czy spacer, co prawda, nie należą do obowiązków rodzinnych, acz stanowią fragment życia rodzinnego i są jednocześnie czynnościami czasu wolnego. Nie jest zatem nadużyciem posługiwanie się wymiennie w tym kontekście obiema kategoriami.

Według Bohdana Junga pojęcie work-life balance jest reakcją na przedłużanie i intensyfikowanie czasu pracy oraz mody czy konieczności pracoholizmu, jakie towarzyszą w krajach wysoko rozwiniętych nowej fazie rozwoju kapitalizmu postmodernistycznego (por. Jung, 2003, s. 17). W związku z tym ważna jest postawa pracownika i pracodawcy, których działania mogą ułatwiać lub utrudniać zachowanie równowagi między pracą zawodową a sferą życia prywatnego (por. Jacobs, Schain, 2009). Istotne wydaje się być postrzeganie tych dwóch sfer życia 
jako komplementarnych, a nie przeciwstawnych względem siebie czy rozłącznych, co oznacza przyjęcie koncepcji holistycznej i traktowanie kariery jako integralnej części życia, a nie jako osobnego obowiązkowego zajęcia. Nie znaczy to jednak, że życie prywatne powinno się prowadzić w pracy, a zawodowe w sferze osobistej. Wręcz przeciwnie w work-life balance istotne jest wyraźne rozdzielenie życia prywatnego i zawodowego i nieprzekraczanie wyznaczonych granic.

$\mathrm{Na}$ idę równoważenia pracy zawodowej i życia prywatnego wydaje się właściwe spojrzenie z trzech perspektyw: jednostki, czyli pracownika, organizacji oraz społeczeństwa.

Znalezienie odpowiedniej równowagi między życiem zawodowym i prywatnym jest wyzwaniem dla wszystkich pracowników, zwłaszcza pracujących rodziców. Umiejętność skutecznego łączenia pracy, obowiązków rodzinnych i życia osobistego jest ważna dla dobrego samopoczucia wszystkich członków gospodarstwa domowego. Ważnym aspektem równowagi między życiem zawodowym a prywatnym jest ilość czasu, jaką dana osoba spędza w pracy. Dowody wskazują, że długie godziny pracy mogą niekorzystnie wpływać na zdrowie osobiste, zagrażać bezpieczeństwu i zwiększać stres.

Im więcej ludzie pracują, tym mniej czasu mogą poświęcić na inne czynności, takie jak czas z innymi, spędzanie wolnego czasu, jedzenie lub spanie. Ilość i jakość czasu wolnego jest ważna dla ogólnego samopoczucia ludzi i może przynieść dodatkowe korzyści dla zdrowia fizycznego i psychicznego (por. Wieczorek, 2008, s. 101).

Poza prywatnymi korzyściami należy zauważyć wymiar zawodowy. Perspektywa organizacji pozwala w ramach koncepcji work-life balance wykorzystywać mechanizm poprawy jakości pracy i życia, bowiem wzmacnia się zaangażowanie pracowników, ich lojalność, a dzięki dopasowaniu trybu i charakteru pracy do potrzeb i kompetencji danego pracownika wzrasta jego produktywność. Ze względu na dużą zależność pomiędzy poziomem zaangażowania pracownika a stopniem zadowolenia klienta efekt ten dodatkowo się uwielokrotnia. Pracownik staje się bardziej kreatywny, a przy tym skupiony na pracy, a także lojalny, co przekłada się na przywiązanie i stałość klientów. Firma może też poczynić oszczędności, nie będąc zmuszana do ponoszenia kosztów związanych z absencją pracowników czy fluktuacją kadr, często towarzyszącą niestabilności zatrudnienia.

Korzyści z omawianej koncepcji i jej rozwiązań przenoszą się na zewnętrzne otoczenie, budując pozytywny wizerunek firmy w środowisku, dzięki czemu budzi ona zainteresowanie i przyciąga dobrych kandydatów do pracy, a jednocześnie łatwiej jest zapobiegać odpływowi pracowników do konkurencji. Zjawiskiem negatywnym może być jednak angażowanie przez taką organizację pracowników, którzy pragną wyłącznie czerpać korzyści i w efekcie stać się ciężarem dla firmy.

Perspektywa najszersza - społeczeństwo - uwzględnia wpływ realizacji idei work-life balance na większą możliwość znalezienia zatrudnienia szczególnie przez kobiety aż po stabilność zatrudnienia. Ma to niezwykle istotne znaczenie dla 
podejmowania decyzji o założeniu rodziny i sprzyja umacnianiu się więzi pomiędzy partnerami, co przekłada się na spadek liczby rozwodów i niepełnych rodzin (por. Kalinowska, 2008, s. 98). Otwiera się w tym samym szansa na podniesienie poziomu i jakości życia kobiet, ale i mężczyzn.

Organizacja Współpracy Gospodarczej i Rozwoju (OECD), która prowadzi badania na temat równowagi pomiędzy życiem prywatnym a zawodowym w państwach członkowskich, wskazuje, że w 2020 r. Polska uzyskała 6,1 pkt w 10-stopniowej skali, czyli poniżej średniej OECD wynoszącej 6,5. Plasuje się powyżej średniej pod względem bezpieczeństwa osobistego, a także wykształcenia i umiejętności, ale poniżej średniej pod względem stanu zdrowia, dochodów i zamożności, powiązań społecznych, zaangażowania obywatelskiego, subiektywnego samopoczucia, pracy i zarobków, jakości środowiska, równowagi między życiem zawodowym a prywatnym (zob. How's Life?, 2020). W Polsce 6\% pracowników pracuje bardzo długo, ale mniej niż średnia OECD wynosząca $11 \%$. Pracownicy etatowi poświęcają średnio $60 \%$ swojego dnia, czyli 14,4 godziny, na opiekę osobistą (jedzenie, spanie itp.) oraz wypoczynek (spotkania towarzyskie z przyjaciółmi i rodziną, hobby, gry, korzystanie z komputera i telewizji itp.) - mniej niż średnia OECD wynosząca 15 godzin (zob. Work-Life Balance, 2020).

Zaprezentowane powyżej dane pokazują, że w Polsce do uzyskania przez kobiety zadowolenia, dobrostanu we wszystkich sferach życia bez potrzeby podejmowania trudnych decyzji jest nadal wiele do zrobienia. Może to być szczególnie ważne wyzwanie dla andragogiki, zajmującej się procesami kształcenia, wychowania, samokształcenia i samowychowania dorastającej młodzieży oraz ludzi dorosłych (por. Turos, 1993, s. 5).

Jedną z ważnych tak dla edukacji dorosłych, jak i dla całego systemu oświatowego jest koncepcja kształcenia całożyciowego opracowana przed 1928 r. przez A. Basile Yeaxlee, a wyłożona w książce pt. Lifelong Education (zob. Suchodolski, 2003, s. 40). Od tego czasu liczne zachodzące procesy i zjawiska oświatowe skłaniają do refleksji, że nieustannie wzrasta znaczenie edukacji dorosłych, w której należy uwzględniać ciągle zmieniające się szybko uwarunkowania. Wpisuje się $\mathrm{w}$ to podejście również potrzeba edukacji dorosłych w zakresie work-life balance. Ze względu na mocno zakorzenione w tradycji odmienne role społeczne kobiet i mężczyzn oświata dorosłych powinna uwzględniać, nie dla pogłębiania podziałów, ale dla lepszego zrozumienia potrzeb obu stron, oddzielnie te dwie perspektywy.

Model andragogiczny (zob. Karawajczyk, 2009, s. 95-108), zakładający możliwość projektowania edukacji osób dorosłych, warto wykorzystać również w przypadku projektowania różnych form nauki w ramach zarówno edukacji formalnej, jak i pozaformalnej uwzględniającej tematykę work-life learning i skierowanej do kobiet. Organizatorzy edukacji dorosłych powinni zwrócić uwagę na kilka kwestii charakterystycznych dla podejścia andragogicznego. 
Harmonia między pracą a czasem wolnym przynosi lepsze efekty niż praca ponad siły. Korzyści z utrzymywanej równowagi przekładają się na efektywność i motywację do pracy oraz satysfakcję z życia rodzinnego. Dopóki zapracowanym kobietom, wyczekującym na chwilę wolnego, nie uświadomi się, dlaczego powinny się uczyć równoważenia obu sfer życia, dopóty będą one traktowały tego typu szkolenia jako nic niewnoszące w ich życie. Bowiem kluczowa reguła, mówiąca o tym, że dorośli „,musza wiedzieć, dlaczego”, zanim zaangażują się w uczenie się, stała się podstawa do sformułowania powszechnie dziś akceptowanej przestanki włączania dorostych uczniów we wspólny proces planowania ich uczenia się (Knowles, Holton, Swanson, 2009, s. 165).

Współczesne kobiety w pełni zdają sobie z tego sprawę, że są odpowiedzialne za swoje życie i podejmowane decyzje oraz są gotowe ponosić ich konsekwencje. Spodziewają się, że w taki sam sposób patrzy na nie otoczenie. Jeżeli w procesie kształcenia czy szkolenia ogranicza się ich samodzielność, doprowadza się do powstania w nich wewnętrznego konfliktu, gdyż z jednej strony, przywołując w pamięci warunki i doświadczenia związane z nauką w szkole podstawowej czy średniej, przybierają postawę uległości, z drugiej strony ich autonomia jest na tyle ugruntowana, że źle się czują, gdy ktoś im coś z góry narzuca (por. tamże, s. 173). Dlatego oferta edukacyjna dla nich nie powinna posługiwać się metodami podawczymi, lecz wykorzystywać metody aktywizujące, zapewniające większe usamodzielnienie edukacyjne.

Tak jak inne oczekiwania wobec realizacji koncepcji work-life balance mają kobiety i mężczyźni, tak też odmienne są doświadczenia z tym związane obu płci, toteż w edukacji dorosłych należałoby również zwracać na to uwagę, bowiem bogactwo doświadczeń wywiera wieloraki wpływ na proces uczenia się (zob. Kolb, 1984). W projektowaniu procesu uczenia się kobiet ich doświadczenie staje się podstawą empiryczną, która sama w sobie warta jest poznania. Opłaca się zatem stosować takie metody, by odwoływać się do tych doświadczeń, a także aby uczestniczki procesu edukacyjnego mogły się wzbogacać o nowe. Odpowiednie będą ku temu dyskusje czy rozwiązywanie problemów, które wykorzystują nabytą wcześniej wiedzę i umiejętności, a także ćwiczenia symulacyjne umożliwiające doskonalenie życiowych, konkretnych umiejętności oraz uczenie się na błędach popełnianych w bezpiecznej sytuacji ćwiczeniowej.

Wymiana doświadczeń między kobietami posłuży zrodzeniu się nowych idei i umiejętności, i nadawaniu im głębszego znaczenia. Nie bez znaczenia dla procesu uczenia się jest powiązanie wcześniejszych i nowo nabytych kompetencji.

W podejściu andragogicznym wykorzystuje się charakterystyczną dla edukacji dorosłych różnorodność. Niejednolita pod względem wiekowym, mająca zróżnicowane przygotowanie, doświadczenia, zainteresowania, zdolności, style uczenia się grupa kobiet $\mathrm{z}$ jednej strony wymaga indywidualnego podejścia, a z drugiej strony przez swoją różnorodność przyczynia się do lepszych efektów pracy dydaktycznej. Dlatego coraz częściej spotyka się projekty, które doceniają 
taką niejednolitość, która ma służyć wymianie doświadczeń. Przykładem takiego działania w zakresie problematyki work-life balance może być projekt Erasmus Plus, nr 2019-1-FR01-KA204-063048 „Wspomaganie przedsiębiorczości kobiet MINDSET”. Projekt rozpoczęto 04.11.2019 r., a zakończy się on 03.11.2021 r. Jego celem jest promowanie i rozwijanie przedsiębiorczości i samozatrudnienia poprzez opracowanie programu szkoleniowego dla kobiet zagrożonych wykluczeniem społecznym i ekonomicznym. To właśnie one są grupą docelową projektu. Jednym z rezultatów głównych jest podręcznik dotyczący work-life balance odnoszący się do specyfiki wynikającej z prowadzonej przez kobiety działalności biznesowej i godzenia jej z życiem osobistym.

Realizacja działań we współpracy międzynarodowej przynosi wiele wymiernych korzyści. Doświadczenia związane z pracą zawodową, rolami małżonków, rodziców czy formami spędzania wolnego czasu są inne w związku także z odmiennością kulturową, co pomaga spojrzeć na zagadnienie równowagi pracy zawodowej i życia osobistego kobiet z zupełnie innej perspektywy i zdobyć zupełnie nowe w tym względzie doświadczenie.

Analiza procesu uczenia się człowieka dorosłego udowodniła między innymi, że zasadniczą rolę w tym procesie odgrywa motywacja wewnętrzna (por. Wygotski, 1971, s. 36). Jej źródłem może być nauka w zróżnicowanym środowisku, gdyż kobiety, widząc, że inne przedstawicielki tej samej płci, należące do różnych grup wiekowych i kręgów kulturowych, wykonujące różne zawody, chcą się edukować, by łatwiej i lepiej osiągać harmonię zawodowej i prywatnej sfery życia, będą także zgłębiały to zagadnienie, aby móc skuteczniej harmonijnie łączyć życie zawodowe z prywatnym. W andragogice przyjmuje się, że osoby dorosłe przejawiają większą gotowość do uczenia się, kiedy w swoim życiu odczuwają potrzebę znajomości czegoś, ze względu na to, że pozwala to skuteczniej działać lub daje satysfakcję.

Znajomość i świadomość potrzeb dorosłych kobiet chcących podjąć naukę z problematyki work-life balance umożliwia adragogowi, organizującemu edukację dorosłych, podjęcie odpowiednich działań, by ułatwić proces przyswajania treści przez uczące się kobiety. Wytworzenie sprzyjającej atmosfery odgrywa tutaj podstawową kwestię. Oprócz klimatu panującego w procesie kształcenia lub szkolenia ważne jest zwrócenie uwagi na klimat wewnątrz instytucji, o ile szkolenie objęło pracowników danej organizacji. Niezależnie od tego nauce kobiet sprzyjają: wzajemny szacunek, atmosfera raczej współpracy niż rywalizacji, wzajemne zaufanie, serdeczna i przyjazna atmosfera.

Częste pytanie, na które poszukuje odpowiedzi andragog, brzmi: jakie procedury należy zastosować w celu wciągnięcia uczących się do procesu planowania wszystkich przedsięwzięć związanych z kształceniem. Nie ulega natomiast kwestii, iż wspólne planowanie, diagnozowanie potrzeb edukacyjnych, formułowanie celów zaspokajających te potrzeby, projektowanie wzoru doświadczeń edukacyjnych, kierowanie owym doświadczeniem z pomocą odpowiednich technik i środków, ocena efektów kształcenia i ponowne zdiagnozowanie potrzeb edukacyjnych 
stanowi istotę edukacji ludzi dorosłych (por. Knowles, Holton, Swanson, 2009, s. 107-123). W przypadku work-life balance kobiet pozwala to lepiej rozpoznać potrzeby edukacyjne uczestniczek procesu edukacyjnego, by móc przełożyć je na cele kształcenia, a więc określić kierunek rozwoju. Kolejnym etapem jest partycypacja kobiet w opracowaniu planu osiągnięcia wyznaczonych celów, który powinien uwzględniać zbiorowe doświadczenia całej grupy oraz doświadczenia poszczególnych kobiet. Takie podejście zapewni na koniec wymierne efekty. Model andragogiczny wymaga, aby uczestniczki procesu uczenia brały również aktywny udział w ocenianiu stopnia realizacji celów (por. Karawajczyk, 2009, s. 105).

Work-life balance kobiet jest pewnym wyzwaniem dla andragogiki. Jednakże nauczyciele, edukatorzy i trenerzy, organizujący kształcenie dorosłych, mają do dyspozycji model andragogiczny, do którego się stosując, mogą efektywnie przygotowywać kobiety do harmonijnego godzenia życia zawodowego z prywatnym. Dzięki takiemu podejściu możliwe jest ukształtowanie postawy aktywnej u kobiet, radzenia sobie $\mathrm{z}$ trudnościami godzenia życia zawodowego i prywatnego, a także podejmowanie wysiłków umysłowych i fizycznych, by sprostać temu zadaniu. Uwypuklenie znaczenia uczenia się nieformalnego w edukacji dorosłych, zanurzenie $\mathrm{w}$ doświadczeniu, uczenie się z własnego życia, dokonywanie później rekonstrukcji minionych wydarzeń i podejmowana nad nimi refleksja stają się najbardziej adekwatnym dla współczesności sposobem uczenia się w sytuacji zachodzących zmian (por. Wojciechowska, 2019, s. 116).

\section{Zakończenie}

1. Praca zawodowa kobiet nie budzi dziś w Polsce kontrowersji. Kobiety tak jak mężczyźni mają prawo realizować się zawodowo zgodnie ze swoimi preferencjami. Nadal jednak aktywność zawodowa kobiet jest niższa niż mężczyzn. Kobiety także rzadziej, mimo swoich kompetencji, awansują na prestiżowe stanowiska.

2. Czas wolny jest kategorią uznawaną za wartość w życiu każdego człowieka. Jego istotę stanowi autonomiczny wybór jednostki, jak ma on zostać zagospodarowany. Kobiety odczuwają deficyt czasu wolnego, gdyż mają więcej od mężczyzn obowiązków rodzinnych. Kiedy jednak nim dysponują, najczęściej czytają książki, uczestniczą w plenerowych wydarzeniach kulturalnych, chodzą do kina i biorą udział w koncertach. W mniejszym stopniu wykorzystują czas wolny na uprawianie sportu, zwłaszcza systematycznie.

3. Praca zawodowa i czas wolny są składowymi budżetu czasu. $Z$ potrzeby umiejętnego połączenia tych dwóch składowych zrodziła się idea work-life balance, dążąca do poprawy jakości pracy i życia w ogóle. Aktywne zawodowo kobiety, borykające się z deficytem czasu wolnego, odnaleźć mogą w tej koncepcji pewne wskazania dla siebie. Niemniej jednak sieć wsparcia ma kluczowe znaczenie zarówno w pracy, jak i poza nią. Wsparcie to może przybierać różne formy. $\mathrm{W}$ organizacji sprowadza się najczęściej do skutecznego zarządzania w niej 
własnym kapitałem ludzkim. W życiu prywatnym partnerzy mogą pomóc sobie wzajemnie skupić się na tym, co jest ważne, zaplanować swój czas, by żyć zdrowo i dokonywać przemyślanych wyborów dotyczących pracy, podróży, zarządzania domem i zaangażowania społecznego.

Warto również, by w kontekście równoważenia życia zawodowego z osobistym móc skorzystać ze wsparcia, jakie daje edukacja dorosłych w jej różnych formach. Pomocne w tym względzie są założenia idei work-life balance i modelu andragogicznego. W oparciu o te dwie silne podstawy możliwe jest tworzenie odpowiednich programów, które wdrażane w różnych organizacjach zwiększą szanse zawodowe kobiet.

\section{Bibliografia}

Aleksander, T. (2009). Andragogika. Radom - Kraków.

„Ariadna” (2018). Życie kulturalne i sposoby spędzania czasu wolnego Polaków (sondaż). Pobrane z: https://ciekaweliczby.pl/zycie-kulturalne-sposoby-spedzania-czasu-wolnego-polakow/ [dostęp: 14.01.2021].

Brak autora (2016). How's Life? Pobrane z: http://www.oecdbetterlifeindex.org/countries/ poland/ [dostęp: 31.12.2020].

Brak autora (2020). Work-Life Balance. Pobrane z: http://www.oecdbetterlifeindex.org/ topics/work-life-balance/ [dostęp: 31.12.2020].

Czapiński, J., Panek, T. (red.). (2013). Diagnoza społeczna 2013. Warunki i jakość życia Polaków. Pobrane z: http://www.diagnoza.com [dostęp: 13.01.2021].

Dumazedier, J. (1960). Problèmes actuels de la socjòlogie du doisir. RISS. Vol. 12. No 4. Paris: UNESCO. Za: S. Czajka (1979). Z problemów czasu wolnego. Warszawa: CRZZ.

Dickisson, K. (1997). Telecommuting got your homework done? Benefits of a flexible work option that is gaining currency in the ' $90 \mathrm{~s}$, and how to get around its potential pitfalls. CMA Magazine, vol. 70, $\mathrm{nr}$ 10, s. 13-14.

Fuszara, M. (2007). Kobiety w polityce. Warszawa.

Gąciarz, B. (2011). Praca kobiet w Polsce: od egalitarnego przymusu ekonomicznego do elitarnej swobody wyboru i powszechnej nierówności statusu. W: K. Slany, J. Struzik, K. Wojnicka (red.), Gender w społeczeństwie polskim. Kraków.

Giddens, A. (2012). Socjologia. Warszawa: Wydawnictwo Naukowe PWN.

Główny Urząd Statystyczny (1969). Spis kadrowy 1968 r.: poziom wykształcenia pracowników. Warszawa. Za: K. Wrochno (1969). Kobiety w Polsce. Warszawa.

Główny Urząd Statystyczny (2013). Badanie budżetu czasu ludności w 2013 r. Pobrane z: https://stat.gov.pl/obszary-tematyczne/warunki-zycia/dochody-wydatki-i-warunki-zycia-ludnosci/badanie-budzetu-czasu-ludnosci-w-2013-r-,18,1.html [dostęp: 13.01.2021].

Główny Urząd Statystyczny (1998). Budżet czasu ludności 1996. Warszawa.

Główny Urząd Statystyczny (2020). Informacja o rynku pracy $w$ trzecim kwartale 2020 roku. Pobrane z: https://stat.gov.pl/obszary-tematyczne/rynek-pracy/pracujacy-bezrobotni-bierni-zawodowo-wg-bael/informacja-o-rynku-pracy-w-trzecim-kwartale-2020-dane-ostateczne,12,44.html [dostęp: 28.12.2020]. 
Główny Urząd Statystyczny (2004). Kobiety i mężczyźni na rynku pracy 2004. Pobrane z: https://stat.gov.pl/obszary-tematyczne/rynek-pracy/opracowania/kobiety-i-mezczyzni-na-rynku-pracy-2004,1,1.html [dostęp: 11.01.2021].

Główny Urząd Statystyczny (2014). Kobiety i mężczyźni na rynku pracy. Pobrane z: https:// stat.gov.pl/obszary-tematyczne/rynek-pracy/opracowania/kobiety-i-mezczyzni-na-rynku-pracy-2014,1,5.html [dostęp: 11.01.2021].

Główny Urząd Statystyczny (2017). Uczestnictwo w sporcie i rekreacji ruchowej w 2016 r. Warszawa.

Golden, T., Veiga, J. (2005). The Impact of extent of telecommuting on job satisfaction: resolving inconsistent findings. Journal of Management, 31, 2, s. 301-18.

Gromada A., Budacz D., Kawalerowicz J., Walewska A. (2015). Marne szanse na awanse? Raport z badania na temat obecności kobiet na uczelniach artystycznych $w$ Polsce. Pobrane z: https://www.nck.pl/upload/attachments/317998/Marne\%20szanse\%20 na\%20awanse\%20RAPORT.pdf [dostęp: 8.03.2021].

Hass, L. (1996). Aktywność wyborcza kobiet w pierwszym dziesięcioleciu Drugiej Rzeczypospolitej. W: A. Żarnowska, A. Szwarc (red.), Kobieta i świat polityki. Warszawa.

Hochschild, A. (2012). The Second Shift. Working Parents and the Revolution at Home. New York: Viking. Za: Giddens A. (2012). Socjologia. Warszawa: Wydawnictwo Naukowe PWN.

Jacobs, P., Schain, L. (2009). Professional Women: The Continuing Struggle For Acceptance And Equality. Criminal Justice Faculty Publications. Paper 1.

Jarosz, D. (2000). Kobiety a praca zawodowa w Polsce w latach 1944-1956 (główne problemy w świetle nowych badań żródłowych). W: A. Żarnowska, A. Szwarc (red.), Kobieta i praca: wiek XIX i XX: zbiór studiów, t. VI. Warszawa, s. 217-241.

Jung, B. (2003). Work-Life Balance: wracamy do punktu wyjścia? (debata nad czasem wolnym z lat siedemdziesiątych XX wieku). Zarządzanie Zasobami Ludzkimi, $n r$, s. 17-29.

Kalinowska, B. (2008). Równowaga między życiem zawodowym a rodzinnym w perspektywie makroekonomicznej. W: C. Sadowska-Snarska (red.), Równowaga Praca-Życie-Rodzina. Białystok, s. 84-100.

Kamiński, A. (1972). Funkcje pedagogiki społecznej. Warszawa: PWN.

Karawajczyk, W. (2009). Kształcenie dorosłych w ujęciu andragogicznym, Colloquium Wydziału Nauk Humanistycznych i Społecznych. Rocznik I, s. 95-108.

Knowles, M.S., Holton, E.F., Swanson III, R.A. (2009). Edukacja dorostych. Podręcznik akademicki. Warszawa: Wydawnictwo Naukowe PWN.

Kolb, D. (1984). Experiential learning. New Jersey: Prentice Hall.

Kolny, B. (2014). Czas wolny w świetle zrównoważonego rozwoju. Konsumpcja i Rozwój, $n r 2$ (7), s. 28-38.

Kowalska, A. (2000). Kobiety na ryku pracy w Polsce. Gospodarka Narodowa, nr 7-8. Warszawa, s. 47-75.

Krahelska, H. (1932). Praca kobiet w przemyśle współczesnym. Sprawy Robotnicze, nr 10, Warszawa: Instytut Gospodarstwa Społecznego.

Kurland, N., Bailey, D. (1999). Telework: the advantages and challenges of working here, there, anywhere, and anytime. Organisational Dynamics, 28, 2, s. 53-68.

Kurzynowski, A. (2000). Przemiany wzorów karier zawodowych kobiet w latach 1950-1989. W: A. Żarnowska, A. Szwarc (red.), Kobieta i praca: wiek XIX i XX: zbiór studiów, t. VI. Warszawa, s. 189-215. 
Malewski, M. (2007). W poszukiwaniu teorii uczenia się ludzi dorostych. W: T. Aleksander, D. Barwińska (red.), Stan i perspektywy rozwoju refleksji nad edukacja dorostych, Kraków - Radom: Uniwersytet Jagielloński, Instytut Technologii Eksploatacji - Państwowy Instytut Badawczy.

Markowska, D. (1986). Rola kobiety polskiej w rodzinie. W: E. Konecka (red.), Kobiety polskie. Warszawa.

Morawska, W. (1951). Wczasy w świetle badań socjologicznych. Praca i Opieka Społecz$n a, n r 2$, s. $72-73$.

Mrozek, J. (2019). Przemiany pozycji kobiet w PRL-u - wybrane konteksty. Studia Edukacyjne, nr 54. Poznań, s. 257-282.

Pięta, J. (2014). Pedagogika czasu wolnego. Nowy Dwór Mazowiecki.

Piłatowicz, J. (1994). Kadra inżynierska w II Rzeczypospolitej. Siedlce.

Smolalski, A. (1996). Struktura zawodowa nauczycielstwa w Polsce do 1939 roku. Opole.

Stanek, L. (2011). Aktywność rekreacyjno-sportowa młodzieży akademickiej w czasie wolnym. W: D. Mroczkowska (red.), Czas wolny. Refleksje, dylematy, perspektywy. Warszawa: Wydawnictwo Difin, s. 171-178.

Stankiewicz-Mróz, A. (2008). Zmiany w obszarze funkcji personalnej wynikające z implementacji koncepcji ,work life balanced. W: E. Jędrych, A. Pietras, A. Stankiewicz-Mróz (red.), Funkcja personalna w zmieniajacej się organizacji. Łódź: Politechnika Łódzka.

Strzemińska, H. (1970). Praca zawodowa kobiet a ich budżet czasu. Warszawa.

Stypułkowska, M. (1994). Trudna droga kobiet do wykonywania zawodów prawniczych. Palestra, nr 9-10, s. 139-149.

Suchodolski, B. (2003). Edukacja permanentna, rozdroża i nadzieje. Towarzystwo Wolnej Wszechnicy Polskiej. Warszawa.

Tarkowska, E. (2001). Czas społeczny a czas wolny: koncepcje i współczesne przemiany. W: A. Żarnowska, A. Szwarc (red.), Kobieta i kultura czasu wolnego, t. VII. Warszawa, s. 17-33.

Turos, L. (1993). Andragogika ogólna. Siedlce: Wydawnictwo Uczelniane WSKP w Siedlcach.

Wawrzykowska-Wierciochowa, D. (1963). Od przadki do astronautki. Warszawa.

Wieczorek, I. (2008). Konflikt praca-rodzina. Szwedzkie przykłady rozwiązań. W: C. Sadowska-Snarska (red.), Równowaga Praca-Życie-Rodzina, Białystok: Wyd. Wyższej Szkoły Ekonomicznej w Białymstoku, s. 101-107.

Wieruszewski, R. (1975). Równość kobiet i mężczyzn w Polsce Ludowej. Poznań.

Wnuk-Lipiński, E. (1981). Budżet czasu-struktura społeczna-polityka społeczna. Wrocław.

Wnuk-Lipiński, E. (1972). Praca i wypoczynek w budżecie czasu. Warszawa.

Wojciechowska, Z. (2019). Transformatywne uczenie się w sytuacji doświadczenia zmiany zawodowej w kontekście dynamiki ponowoczesnego świata społecznego. Edukacja Dorostych, $n r$ 1, s. 103-118.

Wygotski, L.S. (1971). Wybrane prace psychologiczne. Warszawa: PWN.

Zadrożyńska, A. (1986). Kultura tradycyjna i współczesna kultura robotnicza. W: A. Żarnowska (red.), Wokół tradycji kultury robotniczej w Polsce. Warszawa, s. 50-80.

Żarnowski, J. (2000). Praca zawodowa kobiet w Polsce międzywojennej. W: A. Żarnowska, A. Szwarc A. (red.), Kobieta i praca: wiek XIX i XX: zbiór studiów, t. VI. Warszawa, s. 119-140. 


\section{Źródła audiowizualne:}

Polskie Kroniki Filmowe: Kobiety naszych dni, J. Zelnik, 1951. Dostęp: https://filmpolski. $\mathrm{pl} / \mathrm{fp} /$ index.php?film=427469

\section{HARMONY OF PROFESSIONAL LIFE AND FREE TIME IN THE LIVES OF WOMEN IN POLAND IN AN ANDRAGOGICAL PERSPECTIVE}

Keywords: work-life balance, professional work, free time, time budget, andragogical model.

Summary: Professional activity of women in Poland is a common phenomenon. However, it is most often associated with the deficit of free time in their time budget. This issue is related to the concept of work-life balance, which aims to balance these important spheres of human life. The article deals with the harmony of professional life and leisure time in the lives of women in Poland from the andragogical perspective. It answers the questions of what the professional work and free time in women's lives are and what impact andragogy can have on the harmony of women's professional life and free time. Answers to these questions are built on the basis of the literature on the subject, available statistical data and the results of available research and analyses. The article focuses primarily on adult women who have left formal education.

Dane adresowe:

dr Renata Pomarańska

Uniwersytet Rzeszowski

renep@wp.pl 